\title{
A retrospective review of the histopathological features seen in a series of 4241 endometrial biopsy samples collected from UK Thoroughbred mares over a 25 year period
}

\author{
S. W. Ricketts and Annalisa Barrelet \\ Rossdale \& Partners, Beaufort Cottage Stables, Newmarket, England
}

\begin{abstract}
Summary
A retrospective review of the histopathological features and the groups in which they are most frequently seen in combination, seen in 4214 endometrial biopsy samples collected from UK Thoroughbred mares over a 25 year period revealed data which supports widely held views on their pathogenesis and significance. Endometrial hypoplasia is most commonly seen in young mares with delayed endometrial maturity. Mononuclear cell infiltrations develop in the endometrial stroma as a reflection of local immune responses to challenge by seminal proteins, micro-organisms, environmental debris and the products of pregnancy, during a brood mare's life. Endometrial hyperplasia most commonly persists during delayed post-partum or post-pregnancy failure of uterine involution, more commonly in younger mares. Glandular degenerative changes and stromal fibrosis develop as an inevitable consequence of ageing, eventually leading to endometrial atrophy, a reflection of gynaecological senility. These degenerative changes result in endometrial incompetence, progressively reducing mares' foaling potentials and increasing their potential for barren years, early pregnancy failures and abortions.
\end{abstract}

keywords: $\quad$ endometrial biopsy, histopathological features

Eine retrospektive Analyse histopathologischer Befunde bei der Untersuchung von Endometriumsbiopsieproben von 4241 Vollblutstuten im Vereinigten Königreich über einen Zeitraum von 25 Jahren

Dieser retrospektive Überblick über histopathologische Befunde und ihrer häufigsten Kombinationen anhand eines Untersuchungsgutes von 4214 Endomtriumsbiopsien von Vollblutstuten im Vereinigten Königreich aus den letzten 25 Jahren erlaubt weitgehende Aussagen hinsichtlich ihrer Pathogenese und Bedeutung. Endometriale Hypoplasien werden am häufigsten bei jungen Stuten mit verzögerter endometrialer Reife angetroffen. Mononukleäre Zellinfiltrate innerhalb des endometrialen Stromas sind Ausdruck einer lokalen Immunantwort auf die Herausforderungen während des Lebens einer Zuchtstute: Seminaleiweiße, Mikroorganismen, Zelldetritus und Nebenprodukte der Trächtigkeit. Eine endometriale Hyperplasie persistiert am häufigsten im Zuge einer verzögerten Involution nach Trächtigkeit oder Geburt und wird meistens bei jüngeren Stuten beobachtet. Degenerative Veränderungen der Drüsen und Stromatibrosen sind als unvermeidliche Konsequenzen des Alterns anzusehen. Sie führen unter Umständen zur endometrialen Atrophie, die Ausdruck des gynäkologischen Seniums ist. Diese degenerativen Veränderungen führen zu endometrial bedingten Fertilitässtörungen mit fortschreitender Reduktion der Abfohlrate, einer Verlängerung der Güstzeit sowie Resorptionen und Aborten.

Schlüsselwörter: Endometriumsbiopsie, histopathologische Befunde

\section{Introduction}

Endometrial biopsy is a safe, practical and useful technique which provides an aid to the diagnosis of endometrial pathology in mares (Ricketts, 1975a; Ricketts, 1975b; Kenney, 1977; Shideler et al., 1977; Kenney 1978a; Kenney 1978b; Ricketts, 1978; Doig et al., 1981; Slusher et al., 1985; Van Camp, 1988; Doig and Waelchli, 1993). In UK equine practice, biopsy samples are most commonly collected from mares who repeatedly fail to conceive during the breeding season or from mares during routine postseason barren mare examinations (Rossdale and Ricketts, 1980). The histopathological information gained aids gynaecological treatment and subsequent management, leading to improved chances for conception, either during the immediate or the subsequent breeding season
(Ricketts, 1989a; Ricketts 1989b). The aim of this study was to review the histopathological features of 4241 endometrial biopsy samples collected over a 25 year period from UK Thoroughbred mares and their effect on subsequent fertility potential.

\section{Materials and Methods}

The records of 4241 endometrial biopsy samples collected from UK Thoroughbred mares and examined by the authors, between 1972 and 1997, were retrospectively reviewed and their histopathological features analysed with respect to the age, pre-and post-biopsy breeding history of the mares involved. Histopathological features were clas- 


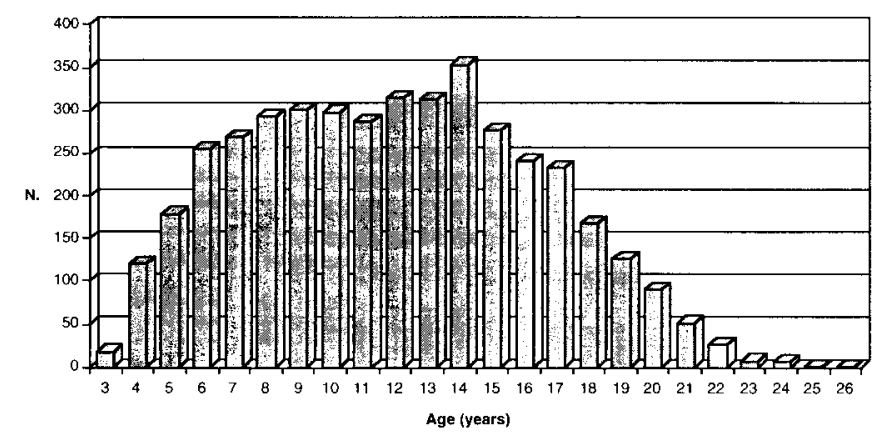

Fig. 1: 4241 Endometrial Biopsy Samples - age of mares at biopsy - frequency distribution histogram.

Lebensalter der untersuchten Stuten ( $n=4241)$ : Häufigkeitsverteilung.

sified as described by Ricketts (1975a; Ricketts 1975b) (Table 1). The histopathological features were frequently seen in combinations, as grouped by Ricketts (1978) (Table 2). Where appropriate, mares were treated before preparation and presentation for mating again (Table 3). Not all mares were re-examined by endometrial biopsy following treatment (Ricketts \& Alonso, 1991a) and therefore follow-up biopsies were not investigated in this survey. Ages, pre- and post-biopsy breeding histories of the mares biopsied were obtained from "The General Stud Book" and its supplements, "The Statistical Record - Return of Mares", published annually by Weatherbys Group Ltd., Wellingborough, Northamptonshire, UK.

Tab. 1: Endometrial Biopsy - Histopathological Features (Ricketts 1975a; Ricketts 1975b).

Endometriumsbiopsie - histopathologische Befunde (Ricketts 1975a; Ricketts 1975b).

\begin{tabular}{|c|c|}
\hline $\begin{array}{c}\text { Histopathological } \\
\text { description }\end{array}$ & Features \\
\hline $\begin{array}{c}\text { Acute Endometritis } \\
\text { (AE) }\end{array}$ & $\begin{array}{c}\text { Polymorphonuclear leucocytes } \\
\text { infiltrating the luminal epithelium } \\
\text { and stroma, sometimes with } \\
\text { eosinophils. }\end{array}$ \\
\hline $\begin{array}{c}\text { Chronic Infiltrative } \\
\text { Endometritis (ClE) }\end{array}$ & $\begin{array}{c}\text { Mononuclear cells, including } \\
\text { histiocytes, and plasma calls, } \\
\text { infiltrating the stroma. }\end{array}$ \\
\hline $\begin{array}{c}\text { Chronic Endometrial } \\
\text { Degenerative Disease } \\
\text { (CDE) (endometrosis) }\end{array}$ & $\begin{array}{c}\text { Glandular degenerative changes } \\
\text { (nests and/or cysts) with } \\
\text { associated periglandular and/or } \\
\text { diffuse stromal fibrosis. }\end{array}$ \\
\hline $\begin{array}{c}\text { Endometrial Atrophy } \\
\text { (EA) }\end{array}$ & Glandular atrophy. \\
\hline $\begin{array}{c}\text { Endometrial Hypoplasia } \\
\text { (EHypo) }\end{array}$ & Glandular hypoplasia. \\
\hline $\begin{array}{c}\text { Endometrial Hyperplasia } \\
\text { (EHyper) }\end{array}$ & Glandular hyperplasia. \\
\hline
\end{tabular}

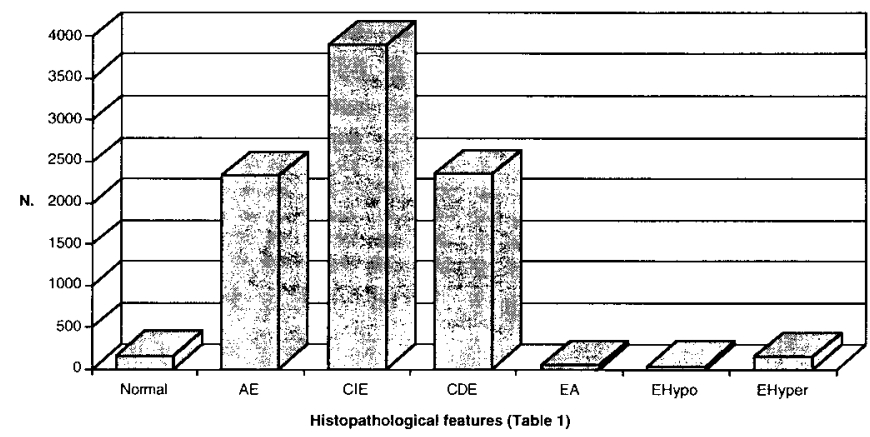

Fig. 2: Endometrial Biopsy Samples - histopathological features - frequency distribution histogram.

Häufigkeitsverteilung der histopathologischen Befunde bei der Untersuchung von 4241 Endometriumsbiopsien.

\section{Results}

The ages, number of foals born and numbers of barren years, early pregnancy failures and abortions suffered by the mares at the time of biopsy collection are shown in the form of frequency histograms (Figs. 1, 2, 3 and 4). The youngest mare examined was 3 and the oldest 26 years old, but the majority ( $81 \%$ ) of the biopsy samples were collected from mares between the ages of 6 and 17 years (Fig. 1), reflecting the age of the active UK Thoroughbred broodmare population. The largest number of foals born to a mare prior to biopsy was 19 (one 24 year-old mare), but the majority $(95 \%)$ of the mares examined had produced

Tab. 2: Endometrial Biopsy Histopathological Feature Combination Groups (Ricketts, 1978) (for key to abbreviations, see Table 1).

Kombinationen histopathologischer Befunde in Endometriumsbiopsieproben (Ricketts, 1978) (Abkürzungen siehe Tabelle 1).

\begin{tabular}{|c|c|}
\hline Histopathological group & Combination of features \\
\hline 1 & No histopathological features \\
\hline 2 & $\mathrm{AE}$ \\
\hline 3 & $\mathrm{CIE}$ \\
\hline 4 & $\mathrm{AE}+\mathrm{CIE}$ \\
\hline 5 & $\mathrm{CDE}$ \\
\hline 6 & $\mathrm{AE}+\mathrm{CIE}+\mathrm{CDE}$ \\
\hline 7 & $\mathrm{CIE}+\mathrm{CDE}$ \\
\hline 8 & $\mathrm{EA}$ \\
\hline 9 & $\mathrm{AE}+\mathrm{EA}$ \\
\hline 10 & $\mathrm{CIE}+\mathrm{CDE}+\mathrm{EA}$ \\
\hline 11 & $\mathrm{EHypo}$ \\
\hline 12 & $\mathrm{EHyper}$ \\
\hline 13 & $\mathrm{AE}+\mathrm{EHyper}$ \\
\hline 14 & $\mathrm{CIE}+\mathrm{CDE}+\mathrm{EHyper}$ \\
\hline 15 & $\mathrm{AE}+\mathrm{CIE}+\mathrm{CDE}+\mathrm{EHyper}$ \\
\hline
\end{tabular}




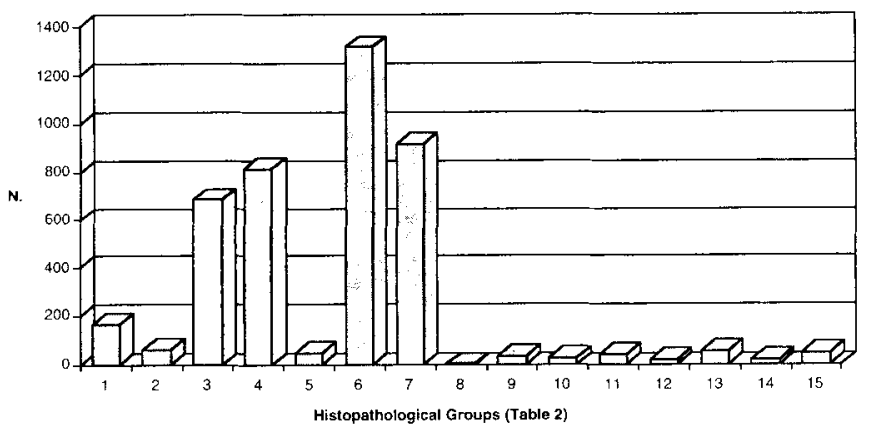

Fig. 3: Endometrial Biopsy Samples - histopathological feature combination groups - frequency distribution histogram.

Häufigkeitsverteilung von Kombinationen histopathologischer Befunde.

between one and 10 foals (Fig. 2). The largest number of barren years prior to biopsy was 11 (one 17 year-old mare), but the majority (96\%) of the mares examined had previously been barren between one and 5 years (Fig. 3). The largest number of early pregnancy failures and abortions suffered by mares prior to biopsy was 4 (one 7 year-old mare) and 5 (two mares, who were 17 and 22 years old) but the majority had suffered 1 or 2 early pregnancy failures or between one and 3 abortions (Figs. 4 \& 5).

The histopathological features seen in the biopsy samples examined are shown in the form of a frequency histogram (Fig. 5). 166 (4\%) showed no significant histopathological features. 3903 (92\%) showed stromal mononuclear cell infiltrations (chronic infiltrative endometritis, CIE), 2356 (56\%) showed chronic glandular degenerative change and stromal fibrosis (chronic degenerative endometrial disease, CDE), 2327 (55\%) showed polymorphonuclear cell infiltration (acute endometritis, AE), 151 (4\%) showed glandular hyperplasia (endometrial hyperplasia, EHyper), 58 (1.4\%) showed glandular atrophy (endometrial atrophy, EA) and $45(1.1 \%)$ showed signs of luminal epithelial and glandular hypoplasia (endometrial hypoplasia, EHypo). 232 mares $(5 \%)$ of the biopsies examined showed signs of diffuse stromal fibrosis. These mares were on average 15.1 years old, had previously produced an average of 5.5 foals and had suffered 2.4 barren years, 0.8 early pregnancy failures and 1.5 abortions.

The histopathological groups classified in the biopsy samples are shown in Table 4 and in the form of a frequency histogram (Fig. 6). $1316(31 \%)$ of the biopsy samples examined had combinations of AE, CIE and CDE (Group 6), 918 (22\%) had CIE and CDE (Group 7), 784 (18\%) had AE and $\mathrm{CIE}$ (Group 4) and 683 (16\%) had CIE (Group 3). All the other groups were classified in less than $1.5 \%$ of the biopsies examined (Table 4). Biopsies with EHypo (Group 11) and those with no significant histopathological features (Group 1) came from the youngest mares (mean ages 5.2 and 7.0 years, respectively) whereas biopsies with EA (Groups 8, $9 \& 10$ ) came from the oldest mares (mean ages 16.0, 17.6 and 18.5 years, respectively). Similar trends were seen with mean numbers of foals born, barren years, early pregnancy failures and abortions suffered (Table 4).
Tab. 3: Treatments used for Endometrial Biopsy Histopathological Features (where appropriate).

Mögliche Behandlungsmethoden bei Vorliegen verschiedener histopathologischer Befunde.

\begin{tabular}{|l|l|}
\hline HP Feature & Treatment \\
\hline AE & $\begin{array}{l}\text { Intrauterine antibiotic irrigations (Ricketts \& } \\
\text { Mackintosh, 1987) +/-Caslick's vulvoplasty } \\
\text { surgery (Ricketts \& Curnow, 1988) }\end{array}$ \\
\hline CIE & None \\
\hline CDE & $\begin{array}{l}\text { Uterine curettage (Ricketts, 1975) if conside- } \\
\text { red excessive for age (Ricketts \& Alonso, } \\
1991 \mathrm{~b})\end{array}$ \\
\hline EA & None \\
\hline EHypo & None \\
\hline EHyper & Intravenous oxytocin infusion (Ricketts, 1978) \\
\hline
\end{tabular}

An analysis of each histopathological group in terms of percentage of foals born, barren years, early pregnancy failures and abortions suffered by mares following biopsy and treatment (where indicated, Table 3) (Table 5) show that foaling percentages were highest for those groups with un-

Tab. 4: Histopathological Feature Combination Groups - numbers and mean ages, foals born, barren years, early pregnancy failures and abortions suffered by mares prior to biopsy.

Vergleich anamnestischer Angaben (mittleres Lebensalter, Abfohlungen, Güstzeit [Jahre], Frühresorptionen [EPF] und Aborte) mit Gruppen, gebildet auf der Basis von histopathologischen Befundkombinationen (siehe Tabelle 2)

\begin{tabular}{|l|r|c|c|c|c|c|}
\hline $\begin{array}{l}\text { Histo- } \\
\text { path. } \\
\text { Groups }\end{array}$ & N. & $\begin{array}{c}\text { Mean } \\
\text { Age } \\
\text { (years) }\end{array}$ & $\begin{array}{c}\text { Mean } \\
\text { Foals } \\
\text { (N.) }\end{array}$ & $\begin{array}{c}\text { Mean } \\
\text { EPFs } \\
\text { (N.) }\end{array}$ & $\begin{array}{c}\text { Mean } \\
\text { Aborts } \\
\text { (N.) }\end{array}$ & $\begin{array}{c}\text { Mean } \\
\text { Barren } \\
\text { (N.) }\end{array}$ \\
\hline 1 & 166 & 7.0 & 1.9 & 0.5 & 0.8 & 1.5 \\
\hline 2 & 62 & 9.6 & 3.3 & 1.3 & 1.4 & 1.7 \\
\hline 3 & 683 & 8.7 & 3.1 & 0.6 & 0.8 & 1.4 \\
\hline 4 & 784 & 8.6 & 2.8 & 0.8 & 1.0 & 1.6 \\
\hline 5 & 46 & 13.0 & 4.3 & 2.0 & 1.2 & 2.7 \\
\hline 6 & 1316 & 14.4 & 5.4 & 0.7 & 1.2 & 2.5 \\
\hline 7 & 918 & 14.3 & 5.5 & 0.6 & 1.0 & 2.4 \\
\hline 8 & 2 & 16.0 & 6.5 & 0 & 1.0 & 2.0 \\
\hline 9 & 33 & 17.6 & 7.7 & 0.6 & 0.9 & 3.3 \\
\hline 10 & 26 & 18.5 & 6.6 & 0.8 & 1.8 & 3.0 \\
\hline 11 & 39 & 5.2 & 0.3 & 0.3 & 0.6 & 1.1 \\
\hline 12 & 21 & 10.0 & 4.2 & 1.0 & 1.3 & 2.1 \\
\hline 13 & 52 & 10.4 & 4.0 & 1.0 & 1.3 & 2.3 \\
\hline 14 & 17 & 11.3 & 3.4 & 0.8 & 1.4 & 1.7 \\
\hline 15 & 50 & 12.3 & 4.2 & 0.8 & 1.5 & 2.5 \\
\hline $\begin{array}{l}\text { All } \\
\text { biopsies }\end{array}$ & 4241 & 11.8 & 4.4 & 0.7 & 1.0 & 2.1 \\
\hline & & & & & & \\
\hline
\end{tabular}


complicated EHyper (Group 12, $81 \%$ ), those with no significant histopathological features (Group 1,75\%), those with EHypo (Group 11, $68 \%$ ) and those with uncomplicated CIE (Group 3, 66\%) and were lowest for those with EA complicated with CIE and CDE (Group 9, 17\%) and EA complicated with AE (Group 10, $21 \%$ ). The foaling percentage for the whole population studied was $54 \%$. The highest early pregnancy failure and abortion rates were seen in biopsies from mares with EA complicated with CIE and CDE (Group $9,4 \%$ and $13 \%$ respectively). The early pregnancy failure and abortion rates for the whole population studied were $2 \%$ and $5 \%$, respectively. For the biopsies with signs of diffuse stromal fibrosis, the mares subsequently showed a foaling percentage of $48 \%$. Their early pregnancy failure and abortion rates were both $3 \%$.

\section{Discussion}

This retrospective survey of the histopathological features seen in 4124 endometrial biopsy samples collected from UK Thoroughbred mares, over a 25 year period, provides data which supports widely held views (Kenney, 1978; Ricketts, 1978; Ricketts, 1995) on their pathogenesis and

Tab. 5: Histopathological Feature Combination Groups - percentages of foals born, barren years, early pregnancy failures and abortions suffered by mares when mates following biopsy and treatment (where indicated)

Vergleich von Kombinationen histopathologischer Befunde mit Parametern, die nach Biopsieentnahme und Therapie (falls indiziert) erhoben wurden: Abfohlrate, Güstzeit, Frühresorption (EPF) und Abort.

\begin{tabular}{|c|c|c|c|c|c|}
\hline $\begin{array}{l}\text { Histopath. } \\
\text { Groups }\end{array}$ & $\begin{array}{c}\text { Foals } \\
(\mathbf{\%})\end{array}$ & $\begin{array}{c}\text { EPFs } \\
(\%)\end{array}$ & $\begin{array}{c}\text { Abortions } \\
(\%)\end{array}$ & $\begin{array}{c}\text { Barren } \\
(\mathbf{\%})\end{array}$ & $\begin{array}{c}\text { NR } \\
\text { Died } \%\end{array}$ \\
\hline 1 & 75 & 0 & 5 & 18 & 2 \\
\hline 2 & 48 & 2 & 2 & 43 & 5 \\
\hline 3 & 66 & 2 & 5 & 18 & 9 \\
\hline 4 & 60 & 2 & 5 & 23 & 10 \\
\hline 5 & 58 & 3 & 0 & 28 & 11 \\
\hline 6 & 43 & 1 & 4 & 31 & 21 \\
\hline 7 & 53 & 2 & 4 & 20 & 21 \\
\hline 8 & 50 & 0 & 0 & 50 & 0 \\
\hline 9 & 17 & 4 & 13 & 39 & 27 \\
\hline 10 & 21 & 0 & 0 & 47 & 32 \\
\hline 11 & 68 & 0 & 0 & 25 & 7 \\
\hline 12 & 81 & 0 & 0 & 19 & 0 \\
\hline 13 & 41 & 0 & 0 & 51 & 8 \\
\hline 14 & 42 & 0 & 8 & 33 & 17 \\
\hline 15 & 55 & 3 & 0 & 29 & 13 \\
\hline All biopsies & 54 & 2 & 5 & 25 & 14 \\
\hline & & & 0 & & \\
\hline
\end{tabular}

${ }^{*} \mathrm{NR}=$ No returns (owners did not complete an official return to Weatherbys) significance. Acute endometritis, most commonly associated with microbial infection, less commonly with non-infectious inflammation induced by intrauterine irritants, is seen in mares of all ages, and is followed by foaling, barren, early pregnancy failure and abortion rates similar to the examined population mean (except for cases complicating endometrial atrophy), suggesting that most respond to treatment. Endometrial hypoplasia is most commonly seen in young mares with delayed endometrial maturity, which usually resolves, without treatment, in time, to normality, Mononuclear cell infiltrations (chronic infiltrative endometritis) develop in the endometrial stroma as a reflection of local immune responses to challenge by seminal proteins, micro-organisms, environmental debris and the products of pregnancy, during a brood mare's life. Uncomplicated, they have no depressant effect on fertility potential and are not an indication for treatment. Endometrial hyperplasia most commonly persists during delayed post-partum or postpregnancy failure uterine involution, more commonly in younger mares. Its resolution may be helped by intravenous oxytocin therapy (Ricketts, 1978). Glandular degenerative changes and stromal fibrosis (chronic degenerative endometrial disease) develop as an inevitable consequence of ageing (Ricketts and Alonso, 1991b), eventually leading to endometrial atrophy, a reflection of gynaecological senility. These degenerative changes result in endometrial incompetence, progressively reducing mares' foaling potentials and increasing their potential for barren years, early pregnancy failures and abortions. Whereas endometrial curettage may appear to have beneficial effects on the degree of CDE seen in endometrial biopsy samples collected before and after treatment in some younger mares (Ricketts, 1975) and return to normal cyclic regularity and pregnancy may reduce the degree of diffuse stromal fibrosis seen in some cases induced by hyperoestrogenism (Ricketts, 1978), no currently recognised treatment can be relied upon to correct these endometrial degenerative changes and careful gynaecological management must be used to help the mare to compensate (Kenney, Bergman, Cooper and Morse, 1975; Ricketts, 1989a; Ricketts 1989b).

\section{References}

Doig, P. A., McNight, J.D. and Miller, R. B. (1981): The use of endometrial biopsy in the infertile mare. Can. Vet. J., 22, 72-76.

Doig. P. A. and Waelchli, R. O. (1993): Endometrial biopsy. In Equine Reproduction. Ed. A. O. MCKinnon and J. L. Voss. Lea and Febiger, 225-233.

Kenney, R.M. (1977): Clinical aspects of endometrial biopsy in fertility evaluation of the mare. Proc. 23rd Ann. Conv. Am. Ass. Equine Practnr., 105-122

Kenney, R. M. (1978a): Cyclic and pathologic changes in the mare endometrium as detected by biopsy with a note on early embryonic death. J. Am. Vet. Med. Ass., 172, 241-262.

Kenney, R. M. (1978b): The role of endometrial biopsy in fertility evaluation. Proc. 24th Ann. Conv. Am. Ass. Equine Practnr., 177-184.

Kenney, R.M. Bergman, R. V., Cooper, W. L. and Morse, G.W. (1975): Minimal contamination techniques for breeding mares: technique and preliminary findings. Proc. 21st. An. Conv. Am. Ass. Equine Practnr. , 327-336. 
Kenney, R. M. and Doig, P. A. (1986): Equine endometrial biopsy. In Current Therapy in Theriogenology, 2nd Edition. Ed. D. A. Morrow, W. B. Saunders, Philadelphia, 723-729.

Ricketts, S.W. (1975a): Endometrial biopsy as a guide to diagnosis of endometrial pathology in the mare. J. Reprod. Fert., Suppl. 23, 341-345.

Ricketts, S.W. (1975b): The technique and clinical application of endometrial biopsy in mares. Equine Vet. J., 7, 102-109.

Ricketts, S.W. (1978): Histological and histopathological studies on the endometrium of the mare. Fellowship Thesis, R.C.V.S., London.

Ricketts, S. W. (1985): Endometrial curettage in the mare, Equine Vet. J., 17, 324-328.

Ricketts, S. W. (1989a): The barren mare: Diagnosis, prognosis, prophylaxis and treatment for genital abnormality. Part 1. In Practice, $11,119-125$.

Ricketts, S. W. (1989b): The barren mare: Diagnosis, prognosis, prophylaxis and treatment for genital abnormality. Part 2. In Practice, $11,156-164$

Ricketts (1995): The non-pregnant mare. In The Equine Manual, Ed. A. J. Higgins \& I. M. Wright, W. B. Saunders Co., 606-617.

Ricketts, S.W. and Alonso, S. (1991a): Assessment of the breeding prognosis of mares using paired endometrial biopsy techniques. Equine Vet. J., 23, 185-188.

Ricketts, S. W. and Alonso, S. (1991b): The effect of age and parity on the development of equine chronic endometrial disease. Equine Vet. J., 23, 189-192.

Rossdale P. D. and Ricketts, S.W. (1980): Equine Studfarm Medicine, 2nd. Edit., Bailliere Tindall, London.

Shideler, R.K., McChesney, A.E., Morrow, G.L., Voss, J.L. and Nash, J. G. (1977): Endometrial biopsy in the mare. Proc. 23rd Ann. Conv. Am. Ass. Equine Practnr., 97-104.
Slusher, S. H., Freeman, K.P. and Roszel, J. F. (1985): Infertility diagnosis in mares using endometrial biopsy, culture and aspirate cytology. Proc. 31st Ann. Conv. Am. Ass. Equine Practnr., 165-170.

Van Camp. S. D. (1988): Endometrial biopsy of the mare -- a review and update. Vet. Clin. N. America: Equine Practice, 4, No.2, 229-245.

\section{Acknowledgements}

We thank our Practice colleagues Peter Rossdale, Nicholas Wingfield Digby, Andrew McGladdery, Sarah Stoneham, Deidre Carson, Simon Abbott and Euan Curnow, plus numerous colleagues from other practices, for help with the collection of endometrial biopsy samples from mares. We thank Kath Gifkins and Hazel Hethershaw for technical assistance, Mary Ashpole, Silvia Alonso, Jenny Kuchel and Nuala Summerfield for help with data recording.

Sidney W. Ricketts, FRCVS

Annalisa Barrelet, MRCVS

Rossdale \& Partners, MsRCVS

Beaufort Cottage Stables

High Street

Newmarket, Suffolk CB8 8JS

England

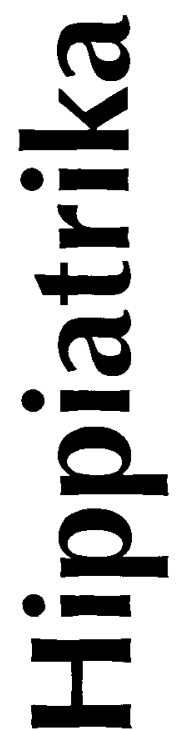

\section{Verlag sucht Tierärztin}

\author{
promoviert oder mit dem Wunsch zu promovieren, \\ zur Mitarbeit bei der Sichtung und Zusammenfassung \\ internationaler Fachliteratur.
}

Anfragen an:

Hippiatrika Verlagsgesellschaft $\mathrm{mbH}$

Herrenberger Straße 7, 72202 Nagold

Telefon (0 74 52) 81381 , Telefax (0 74 52) 81388

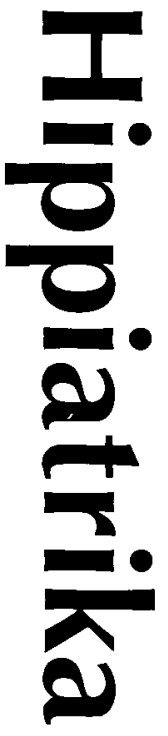

Pferdeheilkunde 13 